\title{
Comparison of chlortenoxicam and indomethacin on frusemide-induced diuresis
}

\author{
A. Hitoglou-Makedou, M. Lawson, P. Turner and H.P. Ferber ${ }^{1}$ \\ Department of Clinical Pharmacology, St. Bartholomew's Hospital, London ECIA 7BE, UK and 'Chemie-Linz \\ AG, Linz, Austria
}

\begin{abstract}
Summary: A single oral dose of chlortenoxicam $4 \mathrm{mg}$, a new non-steroidal anti-inflammatory drug, significantly antagonized the diuretic and natriuretic actions of frusemide when compared with placebo in normal human volunteers. Indomethacin $50 \mathrm{mg}$ significantly reduced the natriuretic, but not diuretic action of frusemide.
\end{abstract}

\section{Introduction}

The diuretic and natriuretic actions of frusemide and other loop and thiazide diuretics are antagonized by concurrent treatment with most, if not all, nonsteroidal anti-inflammatory drugs. ${ }^{1-4}$ Chlortenoxicam is a new non-steroidal anti-inflammatory drug of the oxicam group, ${ }^{5}$ and because it may be given to patients requiring treatment with frusemide it is important to know if it influences frusemide-induced diuresis and natriuresis.

\section{Methods}

Twelve healthy volunteers of either sex (6 females) aged $22-45$ years were studied. The study was doubleblind, randomized and placebo controlled, using a three-way cross-over comparison of chlortenoxicam, indomethacin as a positive control and placebo.

The study was approved by the local ethics committee, every subject gave written consent to participate, and all completed the study.

Volunteers avoided alcoholic and caffeinecontaining drinks for $\mathbf{2 4}$ hours before and during each study day, moderated their intake of foods high in sodium and potassium for 3 days prior to each study day, and avoided medication containing aspirin for one week before each study day. Smoking was prohibited on the study days. The following oral treatments were given at $08.00 \mathrm{~h}$ after an overnight fast and a light breakfast on three separate occasions at least one week apart: chlortenoxicam $4 \mathrm{mg}$, indomethacin $50 \mathrm{mg}$ and matched placebo. One hour

Correspondence: Professor P. Turner, M.D., B.Sc., F.R.C.P. Accepted: 6 June 1989 after each treatment, frusemide $20 \mathrm{mg}$ orally was given. All treatments were taken with $100 \mathrm{ml}$ water. Following administration of frusemide, $100 \mathrm{ml}$ water was given hourly for 6 hours.

Volunteers emptied their bladders before receiving the test treatments and hourly total urine collections were made up to $6 \mathrm{~h}$ after the dose of frusemide. Urine volumes were recorded and $10 \mathrm{ml}$ aliquots stored a $-20^{\circ} \mathrm{C}$ until analysis.

Urinary sodium and potassium concentrations were analysed by automated flame photometry (IL 943 Instrument Laboratory (UK) Ltd). The instrument was calibrated using a standard containing $100 \mathrm{mmol} / \mathrm{l}$ of both sodium and potassium. The calibration was checked and the instrument recalibrated automatically every 16 samples.

An independent running quality sample was analysed every 7 test samples. Coefficients of variation were 0.1 for both sodium and potassium estimations.

The urine volume and total excretion per hour of sodium and potassium were analysed using multiple linear regression analysis with treatments, time of measurements and subjects included as independent variables, using the dummy variable technique. Chlortenoxicam and indomethacin were compared with the placebo.

\section{Results}

Mean values for urinary volume, sodium and potassium excretion associated with the three treatments are shown in Figure 1 and the results of the statistical analysis in Table I. Chlortenoxicam significantly reduced the frusemide-induced diuresis over 6 hours, and both chlortenoxicam and indomethacin reduced the increase in sodium excretion when compared with 
placebo. Neither drug significantly influenced potassium excretion.
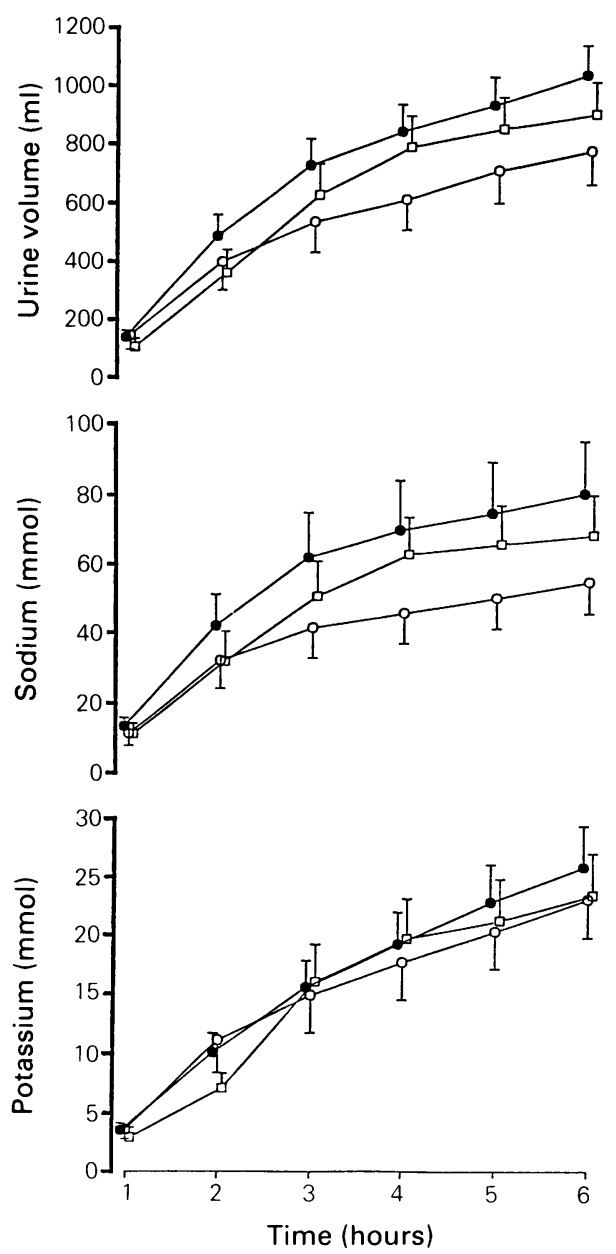

Figure 1 Cumulative urinary volume $(\mathrm{ml})$, sodium and potassium excretion $(\mathrm{mmol})$ per hour over $6 \mathrm{~h}$ following administration of placebo (-), chlortenoxicam $(\mathrm{O}-\mathrm{O}) 4 \mathrm{mg}$ and indomethacin $(\square-\square) 50 \mathrm{mg}$ followed by frusemide $20 \mathrm{mg}$. Each point represents the mean ( \pm s.e.m.) of 12 subjects.

\section{Discussion}

Non-steroidal anti-inflammatory drugs (NSAID) influence renal function in at least two ways. Firstly,
Table I Results of the multiple regression statistical analysis of the effect of chlortenoxicam and indomethacin on urine volume, $\mathrm{Na}^{+}$and $\mathrm{K}^{+}$, compared with placebo

\begin{tabular}{lccc}
\hline $\begin{array}{l}\text { Treatment } \\
\text { (independent variable) }\end{array}$ & $\begin{array}{c}\text { Regression } \\
\text { coefficient }\end{array}$ & $\begin{array}{c}\text { F ratio } \\
(1,197)\end{array}$ & P value \\
\hline $\begin{array}{l}\text { Urine volume } \\
\text { chlortenoxicam }\end{array}$ & -42.71 & 4.20 & $<0.05$ \\
$\quad \begin{array}{l}\text { indomethacin } \\
\text { Na excretion }\end{array}$ & -22.03 & 1.12 & N.S. \\
$\begin{array}{l}\text { chlortenoxicam } \\
\text { indomethacin }\end{array}$ & -4.261 & 5.29 & $<0.025$ \\
$\begin{array}{l}\text { K excretion } \\
\text { chlortenoxicam }\end{array}$ & -3.620 & 3.84 & $<0.05$ \\
indomethacin & -0.599 & 0.92 & N.S. \\
\hline
\end{tabular}

N.S. $=$ not significant

some are known to be nephrotoxic and the early evaluation of new members of this group of drugs should include an assessment of their effects on renal function. Piroxicam, a compound related to chlortenoxicam, has been shown to cause nephrotoxicity in dogs, mice and rats, and there have been reports in man. ${ }^{6,7}$ A recent study of chlortenoxicam in $\stackrel{\mathbb{D}}{2}$ healthy male volunteers showed no evidence of nephrotoxicity in doses up to $6 \mathrm{mg}$ twice daily for two weeks. ${ }^{8}$ A second way in which most, if not all, theseg drugs influence renal function is by antagonizing the diuretic and natriuretic effects of loop and thiazide diuretics. The mechanism of this interaction is uncertain, but may involve inhibition of renal prostaglandin biosynthesis. ${ }^{4}$ Chlortenoxicam appears, from the results of this study, to share with most, if not all, other NSAID the property of antagonizing the diuretic and natriuretic action of frusemide. This potential interaction should be borne in mind when patients receiving frusemide or other loop or thiazide diuretics are considered for treatment with chlortenoxicam.

Only a modest dose of indomethacin was used as a positive control in this study, and it would be unwise to draw any conclusion on the relative effects of indomethacin and chlortenoxicam from the results.

\section{Acknowledgements}

We thank Dr M.R. Al-Sereiti for advice and assistance with the statistical analysis and Dr R. Kohn (Advisory Services, Clinical and General Ltd) for assistance with the protocol. 


\section{References}

1. Bartoli, E., Arras, S., Faedda, R. et al. Blunting of frusemide diuresis by aspirin in man. J Clin Pharmacol 1980, 20: 452-458.

2. Johnston, A., Warrington, S.F., Turner, P. \& Reithmuller-Winzen, H. Comparison of flupirtine and indomethacin on frusemide-induced diuresis. Postgrad Med J 1987, 63: 959-961.

3. Kramer, H.J., Dusing, R., Stinnesbeck, B. et al. Interaction of conventional and antikaliuretic diuretics with the renal prostaglandin system. Clin Science 1980, 59: 67-70.

4. Bartoli, E., Branca, G.F., Faedda, R. et al. Experimental dissociation of the effects of prostaglandins on renal sodium and water reabsorption by cyclo-oxygenase inhibitors in the rat. Br J Pharmacol 1982, 76: 357-360.
5. Ankier, S.I., Brimelow, A.E., Crome, P. et al. Chlortenoxicam pharmacokinetics in young and elderly human volunteers. Postgrad Med J 1988, 64: 752-754.

7. Brogden, R.N., Heel, R.C., Speight, T.M. \& Avery, G.S. Piroxicam: a review of its pharmacological properties and therapeutic efficacy. Drugs 1981, 22: 155-187.

8. Warrington, S.J., Dawnay, A., Johnston, A., Turner, P. \& Ferber, H.P. Chlortenoxicam and renal function of normal human volunteers. Hum Toxicol 1989, 8: 53-54. 